\title{
Shallow gas seismic structures: forms and distribution on Santa Catarina Island, Southern Brazil
}

\author{
Antonio Henrique da Fontoura Klein ${ }^{1}$, Larissa Felicidade Werkhauser Demarco ${ }^{2}$, Vanessa Guesser ${ }^{l}$, \\ Gabriela Reis Flemming ${ }^{1}$, Jarbas Bonetti ${ }^{1}$, Diego Porpilho ${ }^{1}$, Arthur Ayres Neto ${ }^{3}$, Jorge Antonio \\ Guimarães de Souza ${ }^{4}$, Cesár Alexandre Félix ${ }^{5}$ \\ ${ }^{1}$ Universidade Federal de Santa Catarina. Laboratório de Ocanografia Costeira (Campus Reitor João David Ferreira Lima, s/n - \\ Trindade, Florianópolis, SC, CEP: 88040-900. Brazil) \\ ${ }^{2}$ Instituto de Pesquisas Tecnológicas do Estado de São Paulo (Av. Prof. Almeida Prado 532 Cid. Universitária - Butantã. 05508-901 São \\ Paulo/SP. Brazil) \\ ${ }^{3}$ Universidade Federal Fluminense. \\ (Gragoatá Campus - Niterói, RJ, CEP: 24210-350. Brazil) \\ ${ }^{4}$ CB\&I (Rodovia José Carlos Daux 8600 Sala 102, Bloco 3 Florianópolis, SC 88050-000, Brazil) \\ ${ }^{5}$ EGS Brasil. \\ (Rua Joana Folegatti, 127 - Vila Velha, ES, CEP: 29100-500. Brazil)
}

*Corresponding author: antonio.klein@ufsc.br

\begin{abstract}
This paper presents the spatial distribution of shallow gas structures and classifies them on the basis of two different data sets of CHIRP seismic records, one from the Conceição Lagoon (CL) and the other from North Bay (NB), both on Santa Catarina Island, Southern Brazil. Side scan sonar data from the $\mathrm{CL}$ were used to facilitate the understanding. The sub bottom (SB) seismic data were processed and interpreted by means of the SeisPrho software, the side scan sonar (SSS) data by SonarWiz5 software and the spatial extension being measured with the help of GIS. The shallow gas structures were defined in accordance with their shapes in the seismic recordings (echo-character). At the CL, shallow gas accumulations were found in the form of seepages and features presenting shallow gas structures between the surface and $8.20 \mathrm{~ms}$ (around $12.3 \mathrm{~m}$ ). Accumulations of gas were found in the form of Acoustic Blanking with Acoustic Plume, and also Black Shadows. Pockmarks were found on the lagoon floor and associated with gas seepages (average size diameter $0.97 \pm 0.19 \mathrm{~m}$ and density from 54 to 242 units per $50 \mathrm{~m}^{2}$ ). In the NB three types of shallow gas features were found in the seismic profile, namely Acoustic Blanking, Turbidity Pinnacles and Intra-sedimentary plumes. The depth varied from the surface to $12.10 \mathrm{~ms}$ (around $18.15 \mathrm{~m}$ ). In both environments, the gas is escaping from the sediment into the water column. The Pockmarks in the CL and the Acoustic Plume features and sediment rich in total sulfur in the NB validate these findings.
\end{abstract}

Descriptors: Shallow gas features, High resolution seismic, CHIRP, Gas-charged sediments.

\section{RESUMo}

Este artigo apresenta a distribuição espacial das estruturas de gás raso e as classifica com base em dois conjuntos de dados de registros sísmicos diferentes com o CHIRP, um na Lagoa da Conceição (CL) e o outro na Baía Norte (NB), ambos na Illha de Santa Catarina, sul do Brasil. Os dados de sonar de varredura lateral da CL foram usados para facilitar a interpretação. Os dados sísmicos de subsuperfície (SB) foram processados e interpretados por meio do software SeisPrho e os dados obtidos com o sonar de varredura lateral (SSS), pelo software SonarWiz5. A medida espacial foi realizada por intermédio de GIS. As estruturas de gás raso foram definidas de acordo com as formas apresentadas nos registros sísmicos (eco-caráter). $\mathrm{Na}$ $\mathrm{CL}$, as acumulações rasas de gás foram encontradas sob a forma de escapes nas exsudações e feições apresentando estruturas de gás superficial, entre a superfície e 8,20 ms (cerca de 12,3 $\mathrm{m})$. Estas acumulações de gás foram encontradas na forma de Cobertura Acústica com Plumas Acústicas associadas, além de Sombra Negra. As pockmarks foram observadas no fundo da lagoa, ligadas aos escapes de gás (diâmetro médio de 0,97 $\pm 0,19 \mathrm{~m}$ e densidade de 54 a 242 unidades por $50 \mathrm{~m}^{2}$ ). $\mathrm{Na} \mathrm{NB}$ observou-se três tipos de estruturas de gás raso no perfil sísmico, ou seja, de Cobertura Acústica, Pináculos de Turbidez e Plumas Intrssedimentares. A profundidade variou da superfície até 12,10 ms (cerca de 18,15 m). Em ambos os ambientes, o gás é expelido a partir do sedimento para a coluna de água. As pockmarks na CL e na NB, as feições de pluma acústica e os sedimentos ricos em enxofre total validam essa evidência.

Descritores: Feições de gás raso, Sísmica de alta resolução, CHIRP, Sedimentos com gás. 


\section{INTRODUCTION}

The importance of studying shallow gas structures or gas-charged sediments has increased over recent decades. One of the reasons for this is the ongoing effort dedicated to climate change analysis, because such structures may also contribute to global warming, since the gas that escapes from them is mostly methane (BEST et al., 2004). As an example the contribution of methane emission from shallow gas structures and seepages on the continental shelf around the United Kingdom is estimated at $40 \%$ of the total national emission (JUDD et al., 1997). Additionally, the shallow gas structures may represent hazards to coastal engineering works, as they cause sediment instability concerned (PREMCHITT et al., 1992).

The formation of these gas structures results from their sedimentary environment, which may be due to recent sedimentation or human activity, among the evolutionary processes responsible for the characterization of the sedimentary deposition environment (GARCIA-GIL et al., 2002; BALTZER et al., 2005). The accumulation of these gases occurred in former geological periods (i.e., thousands of years before the present), due to the intense oxidization of organic matter in a sedimentary environment (GARCIA-GIL et al., 2002). Transgressive and regressive events over geological time may have changed this sedimentary environment in various ways, so as to have altered the distribution and quantity of the organic matter available at the site, which could thus provide traps to shape various types of gas (GARCIA-GIL et al., 2002). The sandy pockets may create aquifers and/or gas reservoirs, while the finer, mainly muddy sediments may form aquitards and/or sealing layers (GARCIA-GIL et al., 2002; WESCHENFELDER et al., 2006).

The accumulation of these gases may occur on or beneath the surface of the sedimentary column, as well as dissolved in the water column (GARCÍA-GIL et al., 2002). The shallow gas structures occur in various geomorphological features in the form of an Acoustic Blanket (Acoustic Blanking), Acoustic Curtains, Acoustic Columns, Acoustic Turbidity, Turbidity Pinnacles and Intra-sedimentary Plumes, among others types of seismic reflectors (GARCIA-GIL et al., 2002; FRAZÃO; VITAL, 2007; WESCHENFELDER et al., 2006; WESCHENFELDER et al., 2016). The seepage may also occur in the form of Acoustic Plumes and Pockmarks, among others (GARCIA-GIL et al., 2002; FRAZÃO; VITAL, 2007; WESCHENFELDER et al., 2006; WESCHENFELDER et al., 2016).
The spatial distribution of the different types of gas accumulation depends on the grain size, porosity and type of sediment and rock in which the gases are trapped (FRAZÃO; VITAL, 2007). The porosity of the sedimentary facies where the gas accumulates and the sealant facies are the main factors that determine the type of gas accumulation (FRAZÃO; VITAL, 2007). According to LEE et al. (2005), the gas accumulations may have two origins: biogenic (by the action of bacteria that degrade organic matter), usually consisting of methane; and thermogenic (organic structures broken down under the appropriate conditions of temperature and pressure) that produce methane plus other hydrocarbons.

Shallow gas features can be formed in diverse environments such as in sea-beds and on continental shelves (SCHROOT; SCHÜTTENHELM, 2003; EMEIS et al., 2004, respectively), loughs (LAFFERTY et al., 2006) or bays (JENSEN; BENNIKE, 2009; KARNAUKH et al., 2016) and rías (DIEZ etal., 2007; GARCIA-GIL etal., 2002; DUARTE et al., 2007; IGLESIAS; GARCÍA-GIL, 2007), since these environments provide favorable conditions for their formation. In Brazil, the presence of these features has been described by various authors such as VITAL and STATTEGGER (1997) in the lowest stretch of the Amazon River; FIGUEIREDO and NITTROUER (1995) and FIGUEIREDO et al. (1996) in the Amazon submarine delta and COSTA and FIGUEIREDO (1998) on the Amazon Continental Shelf; BAPTISTA NETO et al. (2011) in Rodrigo de Freitas Lagoon - Rio de Janeiro; BENITES et al. (2015) in Saco do Mamangua, Rio de Janeiro; BAPTISTA NETO et al. (1996), QUARESMA et al. (2000) and CATANZARO et al. (2004) in Guanabara Bay, Rio de Janeiro; WESCHENFELDER et al. (2006) in Patos Lagoon - Rio Grande do Sul associated with low-lying paleotopographical features such as paleo river channels and/or valleys; SCHWARZER et al. (2006) in the Rio Açu Canyon and FRAZÃO and VITAL (2007) in the Potengy estuary, both in Rio Grande do Norte; FÉLIX (2012) in the Bertioga Channel, São Paulo; and SOUZA et al. (2011), DEMARCO et al. (2012), GUESSER et al. (2012) and WESCHENFELDER et al. (2016) presented preliminary results for the North Bay and the Conceição Lagoon - on the Santa Catarina Coast (Figure 1). In summary, gas-charged sediment and exhaust gases escaping into the water column occur in Brazil on the continental shelf and in rivers, bays and lagoon systems, from north to south, normally associated with sediments rich in organic matter. 


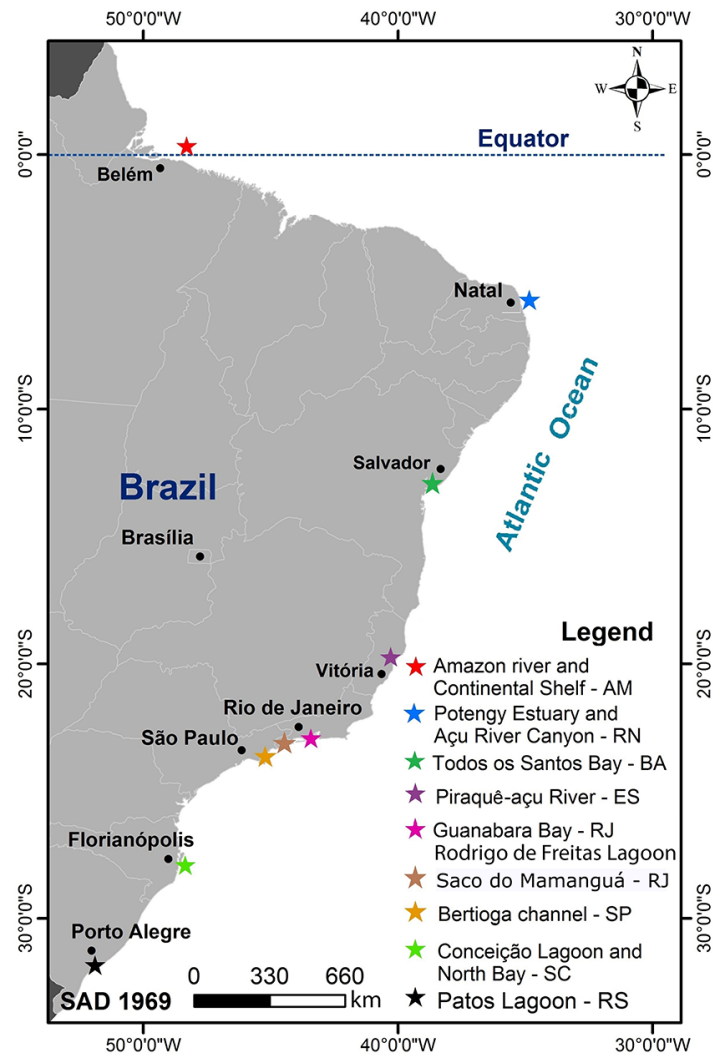

Figure 1. Distribution of shallow gas features, describe in the literature, along the coast and continental shelf of Brazil.

Although there are not many studies describing the gas features, beyond giving their spatial distribution, especially in southern Brazil, the purpose of this study is to specify the distribution of gas-related features, classifying them and describing their characteristics, based on high resolution ultra-shallow water CHIRP seismic recordings of the Conceição Lagoon and the North Bay on Santa Catarina Island, Santa Catarina, Southern Brazil.

\section{STUdy AREA}

The Conceição Lagoon and the North Bay are located on the Rugged Bedrock Headland-Strand Coastal Plain of Santa Catarina State, Southern Brazil, which is a sector dominated by large bedrock headlands, reentrants, bays and lagoon systems (KLEIN et al., 2010; MCBRIDE et al., 2013) (Figure 2). This part of the coast is characterized by the high relief of the nearby Serra do Mar range, with a series of grabens and horsts parallel to the current coastline that were created by the Tertiary collapse (58 M yr BP) of a large Cretaceous plateau (ZALÁN; OLIVEIRA, 2005), giving rise, over the course of 30 million years, to rocky scarps along an elongated E-W rise that separates the Pelotas and Santos marginal basins. The result is a bedrock-dominated coastline, marked by a series of bays and reentrants typically fronted by bedrock headlands. The modern coastline is tectonically inactive (HESP et al., $2009)$ and fronted by the low gradient $(0.01 \%$; ANGULO et al., 2009; CARUSO JR et al., 2000) Florianópolis continental shelf.

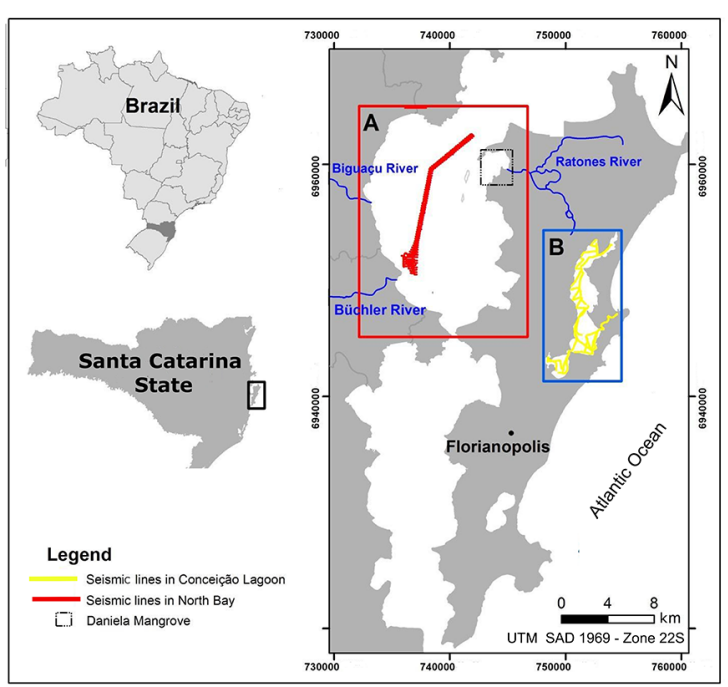

Figure 2. Area of study. A) North Bay; B) Conceição Lagoon.

Large-scale sea-level fluctuations throughout the Quaternary resulted in the deposition of a series of transgressive barriers and regressive barrier-strandplain systems, thus straightening the bedrock-dominated shoreline (DOMINGUEZ, 2009; KLEIN et al., 2010; MCBRIDE et al., 2013; HEIN et al. 2013, 2014). Two Quaternary barriers, dating from the Oxygen Isotopic Stage (OIS) 5e and mid-Holocene highstands (SUGUIO et al., 1985; VILLWOCK et al., 1986; MARTINS et al., 1988) have been identified on the central coast of Santa Catarina where the Serra do Mar mountain range abuts the modern coast (HORN FILHO et al., 1997; CARUSO JR et al., 2000; MCBRIDE et al., 2013; HESP et al., 2009; HEIN et al., 2013, 2014).

Records of the OIS $5 \mathrm{e}(\sim 120 \mathrm{ka})$ highstand are preserved as sandy terraces or barriers along the Santa Catarina Island (HORN FILHO et al., 1997; CARUSO JR et al., 2000, DOMINGUEZ, 2009). Relative sea level at that time was $8 \pm 2 \mathrm{~m}$ above the present level (HORN FILHO et al., 1997; CARUSO JR et al., 2000; DOMINGUEZ, 2009), resulting in the deposition of barrier systems and responsible for the evolution of the Conceição Lagoon and its separation 
from the ocean (HORN FILHO et al., 1997; CARUSO JR et al., 2000). More recently, the eustatic sea-level rise following the last glacial maximum resulted in a highstand approximately $5.8 \mathrm{ka}$ ago, encroaching in some locations upon Pleistocene highstand barriers (HORN FILHO et al., 1997; CARUSO JR et al., 2000, DOMINGUEZ, 2009). Since then the sea level has fallen 2 to $4 \mathrm{~m}$ (SUGUIU et al., 1985; ANGULO; LESSA, 1997; ANGULO et al., 2006; HESP et al., 2009; MCBRIDE et al., 2013; HEIN et al., 2013, 2014) as a consequence of global isostasy, as demonstrated by MITROVICA and MILNE (2002).

The ultimate source of the sediment leading to the development of this coast is largely unknown (KLEIN et al., 2010; MCBRIDE et al., 2013). Due to the proximity of the coastal mountain ranges, drainage is dominantly inland, leaving only small, local riverine sediment sources feeding the Santa Catarina Island and neighboring areas (e.g. Biguaçu River) (KLEIN et al., 2010). The sediments from these rivers formed small delta systems in semienclosed water bodies, with strandplains.

The surface sediment in the Conceição Lagoon is predominately of very fine to fine sand in the shallower areas, and of mud in the deeper ones (GRÉ; HORN FILHO, 1999). The North Bay is predominately muddy, with sediments rich in organic matter and also total sulfur in specific sectors (BONETTI et al., 2007).

\section{MATERIAL AND METHODS}

In the present research, two different data sets were presented: one for the Conceição Lagoon and the other for the North Bay (Figure 2). In the Conceição Lagoon, $53.62 \mathrm{Km}$ of high-resolution seismic lines divided into 30 seismic profiles were surveyed using an Edgetech - 3200 - model SB 512-I -sub-bottom (SB) profiling system. The selected frequency was of 1 to 6 $\mathrm{kHz}$, with a central frequency of $2.5 \mathrm{KHz}, 80 \%$ of power with a ping rate of $7 \mathrm{~ms}$ and a bandwidth of $40 \mathrm{~ms}$ that gives a vertical resolution of about $15 \mathrm{~cm}$. In the North Bay, 83.26 Km of high-resolution seismic lines divided into 142 seismic profiles were surveyed using an Edgetech 3200-model SB216-s, sub-bottom (SB) profiling system. The selected frequency was of 2.5 to $15 \mathrm{kHz}$ with $80 \%$ of power with a ping rate of $7 \mathrm{~ms}$ and a bandwidth of 20 $\mathrm{ms}$, that gives a vertical resolution of about $6 \mathrm{~cm}$. In both surveys a wideband modulated frequency (FM) employing Edge Tech's Full Spectrum CHIRP technology was used.
The term ultra-shallow is used to refer to surveys in water depths between 1 and $10 \mathrm{~m}$.

The data were collected by EdgeTech Discover acquisition and processing software. Position was given by a DGPS system. After their acquisition the seismic data were post-processed and interpreted by means of the open source software SeisPrho (GASPERINI; STANGHELLINI, 2009) this being done spatially with the help of ARCGIS software. Bandpass filter and Automatic Gain Control (AGC) were applied to minimize the noise and to improve the visibility of late-arriving (later occurring) events in which attenuation or wavefront divergence has caused amplitude decay (GASPERINI; STANGHELLINI, 2009).

The shallow gas features were defined in accordance with their shape and echo-character; in the shallow seismic high resolution record the works of GARCIA-GIL et al. (2002), LEE et al. (2005), BALTZER et al. (2005), and TAYLOR (1992) among others were used as reference. The depth of the gas features was measured in milliseconds (ms) and the sound velocity used was $1500 \mathrm{~m} / \mathrm{s}$, so it is possible to estimate the depths of the features in meters.

In the Conceição Lagoon an Interferometer Bathymetry and $540 \mathrm{kHz}$ Side Scan Sonar (SSS) (Edge Tech 4600) were used to map the Pockmarks on the lagoon floor. The data were post-processed and interpreted by the use of the HYPACK and SonarWiz5, being spatially defined with the help of ArcGIS software. Time-variant gain (TVG) was applied to improve the recordings. The Pockmarks' size and density per $50 \mathrm{~m}^{2}$ were obtained in five areas. Additionally, a combination of SSS and SB is presented to improve the analysis and to show the relationship between the gascharged sediment and the exhausted gas (Pockmarks). In situ pictures of gas features and seepages, varying from 20 to $50 \mathrm{~cm}$, were also obtained. Previous data of organic matter and total sulfur, obtained by BONETTI et al. (2007), were compared to seismic high-resolution records in order to evaluate whether the geochemical characteristics of the sediment were related to gas features.

\section{RESULTS}

\section{Classification OF SHALlOW GAS STRUCTURES}

In Table 1 a classification and distribution of the gas structures described in the study area is presented. In Figures 3, 4 and 5 it is possible to observe how the shallow gas structures (echo-characters) are registered in the CHIRP seismic record and SSS. 
Table 1. Shallow gas features' names and their characteristics.

\begin{tabular}{|c|c|c|c|}
\hline NAME & NAME IN LITERATURE & $\begin{array}{c}\text { ACOUSTIC } \\
\text { CHARACTERISTIC }\end{array}$ & AUTHORS \\
\hline 1.Acoustic Plumes & $\begin{array}{l}\text { Plumes; Hydroacoustic } \\
\text { plumes }\end{array}$ & $\begin{array}{l}\text { Discrete hyperbolic curve in the } \\
\text { water column which is related to } \\
\text { free gas bubbles in the water }\end{array}$ & $\begin{array}{l}\text { TAYLOR, (1992); LEE et al., (2005); } \\
\text { GARCIA-GIL et al., (2002); FRAZÃO } \\
\text { and VITAL, (2007); DIEZ et al., (2007); } \\
\text { DUARTE et al., (2007). }\end{array}$ \\
\hline $\begin{array}{l}\text { 2. Intra-sedimentary } \\
\text { Plumes }\end{array}$ & Intra-sedimentary Plumes & $\begin{array}{c}\text { Anomalies consisting of parabolic } \\
\text { reflectors actually crossing real } \\
\text { reflectors }\end{array}$ & $\begin{array}{l}\text { IGLESIAS and GARCÍA-GIL, } \\
\text { (2007); SOUZA et al., (2011). }\end{array}$ \\
\hline 3. Pockmarks & Pockmark & $\begin{array}{l}\text { Craters of different sizes (from } \\
\text { centimeters to meters) in the bed } \\
\text { caused by fluids erupting and } \\
\text { streaming through the sediments; }\end{array}$ & $\begin{array}{l}\text { KING; MCLEAN, (1970); GARCIA- } \\
\text { GIL et al. (2002); IGLESIAS; } \\
\text { GARCÍA-GIL (2007); FRAZÃO and } \\
\text { VITAL (2007). }\end{array}$ \\
\hline 4. Acoustic blanking & $\begin{array}{l}\text { Blankets; acoustic masking; } \\
\text { gas blanket; blanking; } \\
\text { acoustic turbidity }\end{array}$ & $\begin{array}{l}\text { Top of the feature strongly } \\
\text { reflective, continuous, linear; } \\
\text { masks any underlying seismic } \\
\text { recording, preventing the } \\
\text { connection of the gas to its source }\end{array}$ & $\begin{array}{l}\text { MISSIAEN et al. (2002); EMEIS } \\
\text { et al. (2004); ORANGE et al. (2005); } \\
\text { LEE et al. (2005); DIEZ et al. (2007); } \\
\text { DUARTE et al. (2007); JENSEN and } \\
\text { BENNIKE (2009); MAZUMDAR } \\
\text { et al. (2009); SOUZA et al. (2011); } \\
\text { DEMARCO et al. (2012); GUESSER } \\
\text { et al. (2012); WESCHENFELDER } \\
\text { et al. (2006); FRAZÃO and VITAL } \\
\text { (2007); GARCIA-GIL et al. (2002); } \\
\text { MAZUMDAR et al. (2009); } \\
\text { GORGAS et al. (2003). }\end{array}$ \\
\hline 5. Black shadow & Black Shadow & $\begin{array}{l}\text { Accumulation of decomposing } \\
\text { organic matter recent, as can be } \\
\text { seen from the seabed profile. It } \\
\text { is marked by several multiples, } \\
\text { which makes it impossible to } \\
\text { identify any underlying structure }\end{array}$ & $\begin{array}{l}\text { BALTZER et al. (2005); FÉLIX } \\
\text { (2012). }\end{array}$ \\
\hline 6. Turbidity pinnacles & Turbidity pinnacles & $\begin{array}{l}\text { Variation of Acoustic Blanking. } \\
\text { Present an inverted U-shape and } \\
\text { obscure any underlying reflector }\end{array}$ & $\begin{array}{l}\text { IGLESIAS and GARCÍA-GIL (2007); } \\
\text { SOUZA et al. (2011). }\end{array}$ \\
\hline
\end{tabular}

\section{Conceição Lagoon Gas Structures: Forms} AND DiSTRIBUTION

In the Conceição Lagoon shallow gas accumulations were found in the form of leaks and features in 25 of 31 profiles $(13.12 \mathrm{Km})$. Accumulations of gas were in the form of Acoustic Plumes associated with Acoustic Blanking (Figure 3); this feature is characterized as having a strong reflector top presenting a complete absence of underlying seismic data (LEE et al., 2005). There is a complete recording of underlying seismic masking making it impossible to determine stratigraphy or any connection with a gas source. Acoustic Plumes consisting of a series of parabolic high amplitude reflections occur frequently along the seismic line, typically every 100-200 meters (TAYLOR,
1992). Besides, Black Shadows (Figure 3), features that are different from gas curtains in that they permit the acoustic seabed to be reached, are present (BALTZER et al., 2005). Seepages were found in 2 profiles on dark blue lines in the south-central and north portions of Figure 3.

The presence of gases in the lagoon has been confirmed by the Pockmark structures and the presence of Acoustic Plumes in the water. The Pockmarks were mapped and described with the help of the Side Scan Sonar recording and validated by in situ diving and photography (Figure 4). The average size diameter of the Pockmarks is $0.97 \pm 0.19 \mathrm{~m}$ and their density per $50 \mathrm{~m}^{2}$ ranges from 53 to 242 (Figures $5 \mathrm{a}$ to $\mathrm{g}$ ). 


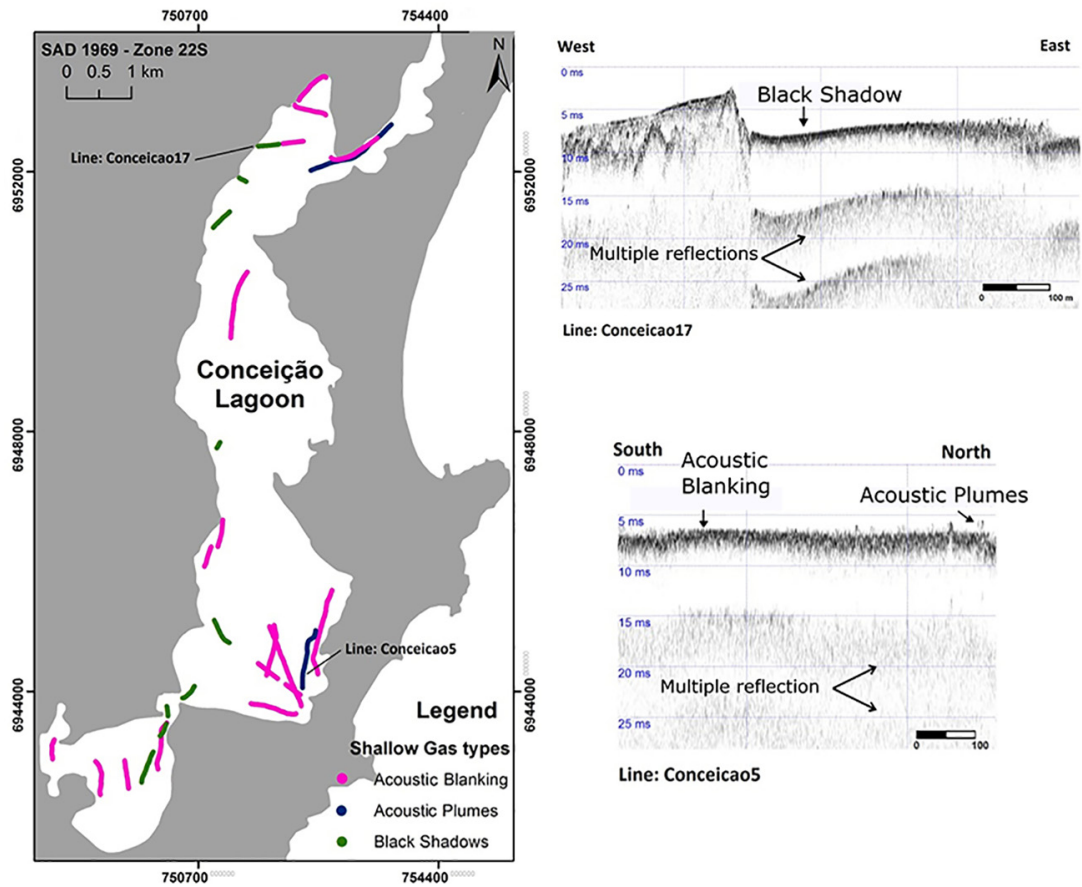

Figure 3. Different structures and distribution of gas features contained within the Conceição Lagoon: Acoustic Blanking with Acoustic Plume and Black Shadow.
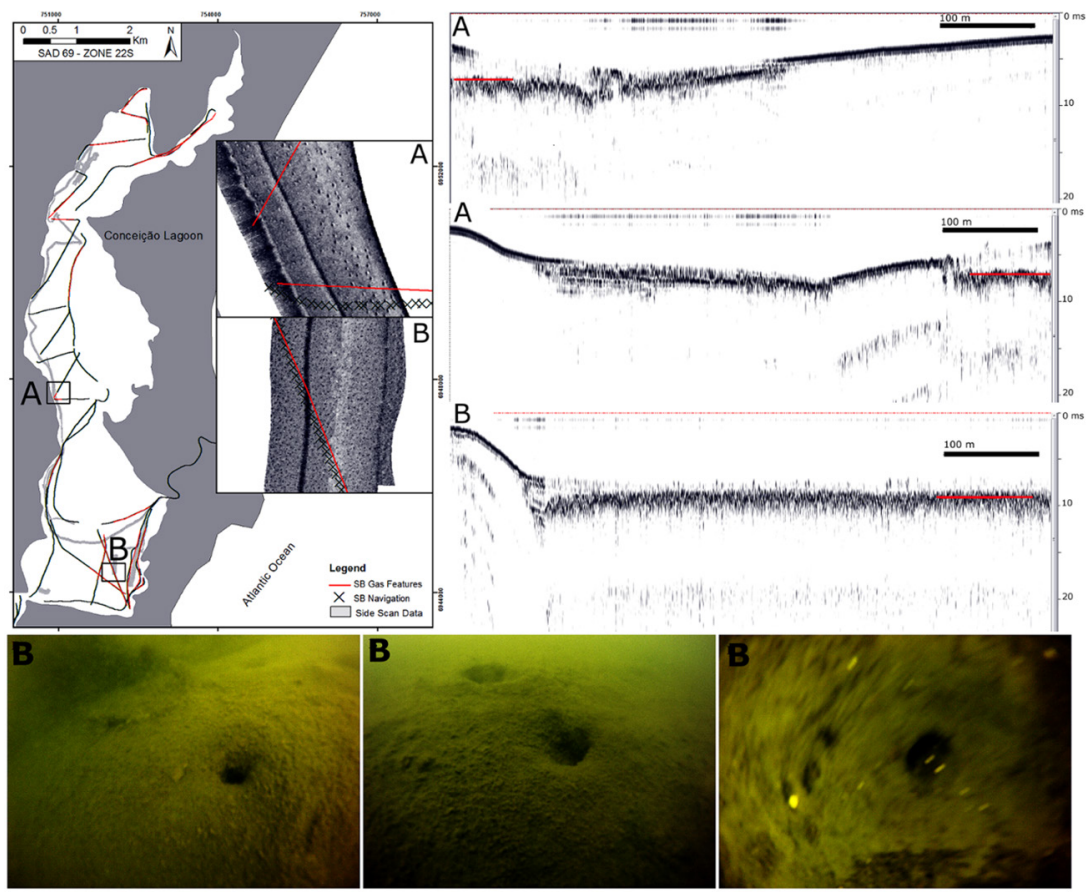

Figure 4. Different structures of gas leaks contained within the Conceição Lagoon: Pockmarks. The correlation between the gas-charged sediments and the Pockmarks in the Conceição Lagoon and Pockmarks photography. It is possible to observe very fine sediment and bobbles escaping the bores. Photo by Diego Porpilho. 


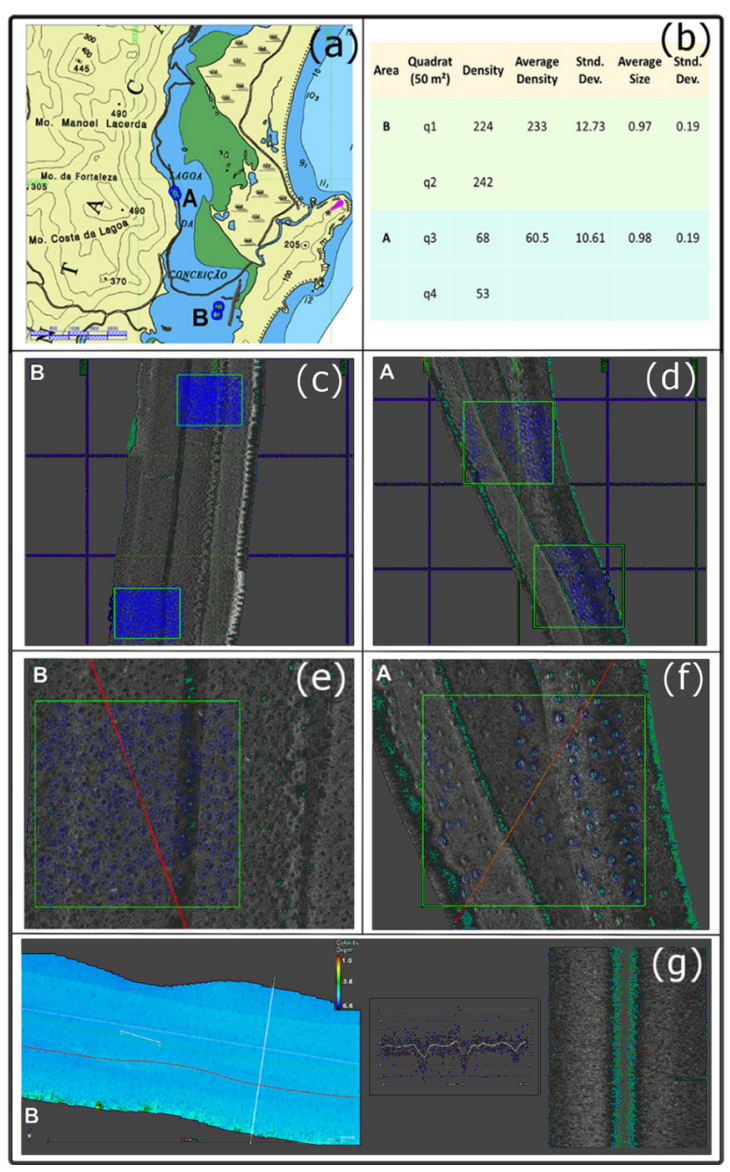

Figure 5. Pockmark distribution, density and size at the Conceição Lagoon. a) Localization of area A and B; b) size and density statistic; c) Area A; d) Area B; e) Zoom at area A; f) Zoom at area B; g) Bathymetry, SSS and 2D morphology of Pockmark.

They are almost linearly oriented and spaced in Area A and well distributed in Area B. In Figure 4, it is possible to observe the correlation between the gas-charged sediments (Acoustic Blanking and Black Shadow) and the Pockmarks. The gas-charged sediments are at the sediment surface $(0-7.9 \mathrm{~ms}$ or down to $6 \mathrm{~m})$ with low to medium amplitude. They are located in sand banks (Acoustic Blanking) and mud channel sediments (Black Shadow), respectively.

The gas echo-characters were identified and thus their depths were calculated in time, with surface profiles to $8.20 \mathrm{~ms}(6.15 \mathrm{~m})$. Figure 6a shows the depth and amplitude (reflectivity) distribution of the different types of gases found in the Conceição Lagoon.

\section{North Bay Gas Structures: Forms AND Distribution}

In the North Bay, from 142 profiles (83.26 Km), 45 showed the presence of gas structures $(40.85 \mathrm{Km})$. In the northern portion near the narrowing of the bay, gases lie at depths between 0.16 and $12.10 \mathrm{~ms}$ or $0.12 \mathrm{~m}$ and $9.8 \mathrm{~m}$ (Figure 7a). There are three types of shallow gas features which appear in the North Bay's seismic profile: Acoustic Blanking, Turbidity Pinnacles and Intra-sedimentary Plumes (Figure 8). Sometimes they are found associated with other features, but normally they occur alone. The most common feature of shallow gas in the North Bay is Acoustic Blanking, normally occurring in the northern part of the bay. It is characterized by a transparent or signalstarved domain in the seismic section, as the result of the attenuation of the acoustic signal caused by gas in the sediments (DUARTE et al., 2007).

The central part of the Bay presents gases with depths from $0.16 \mathrm{~ms}$ to the surface, predominantly as Acoustic Blanking with the presence of Turbidity Pinnacles and Intra-sedimentary Plumes (Figure 8), anomalous features consisting of parabolic reflectors which traverse the sedimentary column (GARCIA-GIL et al., 2002), and in the Bay they come closer to the surface or even right up to the water. These types of echo-characters are present at from low to medium amplitude (Figure 7b).

Turbidity pinnacles which appear as a 'tepee-shaped front', sometimes reaching the seafloor, are most common in the southern part of the study area. Intra-sedimentary plumes are described as features of parabolic anomalies crossing real reflectors (Figure 8).

\section{DISCUSSION}

An extensive terminology is used in the literature to describe the accumulation of gases and a variety of authors have contributed to this classification. An example is the feature type known as Acoustic Cover, which HOVLAND and JUDD (1988) and MAZUMDAR et al. (2009) classified as Acoustic Blanking or Acoustic Masking and JENSEN and BENNIKE (2009), MISSIAEN et al. (2002), DUARTE et al. (2007), GARCIA-GARCÍA et al. (2007), EMEIS et al. (2004), LEE et al. (2005), ORANGE et al. (2005) called Acoustic Blanking; TAYLOR (1992) and FRAZÃO and VITAL (2007) described them as Blankets, GARCIA-GIL et al. (2002) as the Acoustic Blanket. The references show that there is an overlapping of names referring to the classification of the different features, with different names being used for similar accumulations. FÉLIX (2012) mentioned in his study of overlapping names that the Acoustic Curtain is also described as Gas Curtain, Mushroom Type and Mounded Turbidity.

In the Conceição Lagoon it is possible to observe the correlation between the gas-charged sediments (Acoustic 
a)

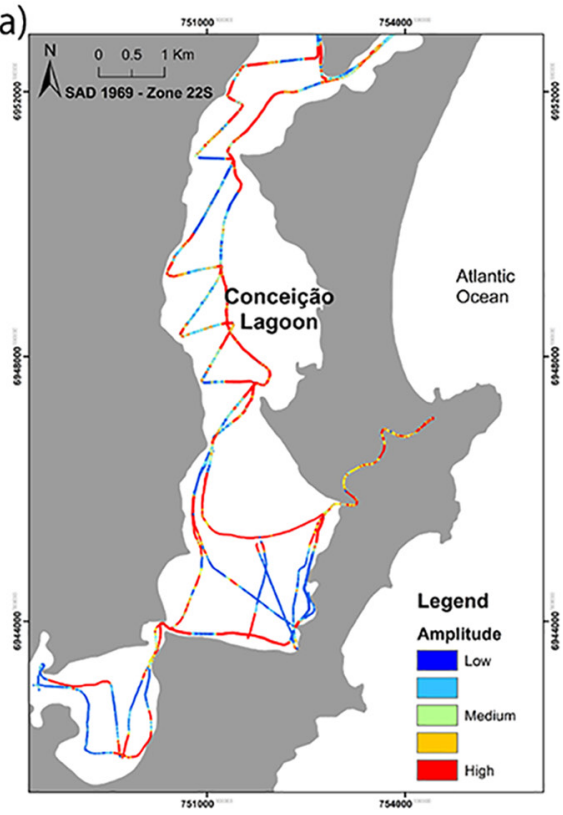

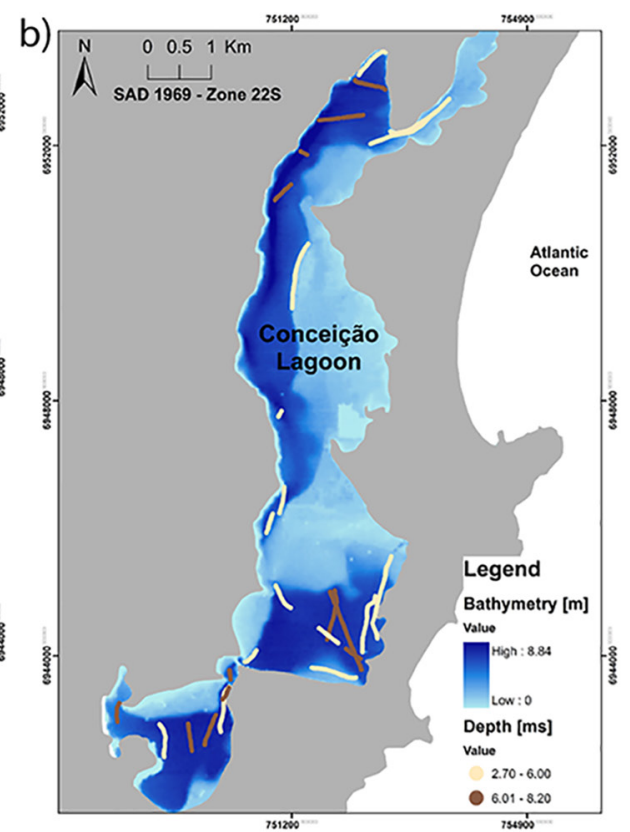

Figure 6. The amplitude (reflectivity) of the Conceição Lagoon floor (a) and the distribution of depths of gas (b).
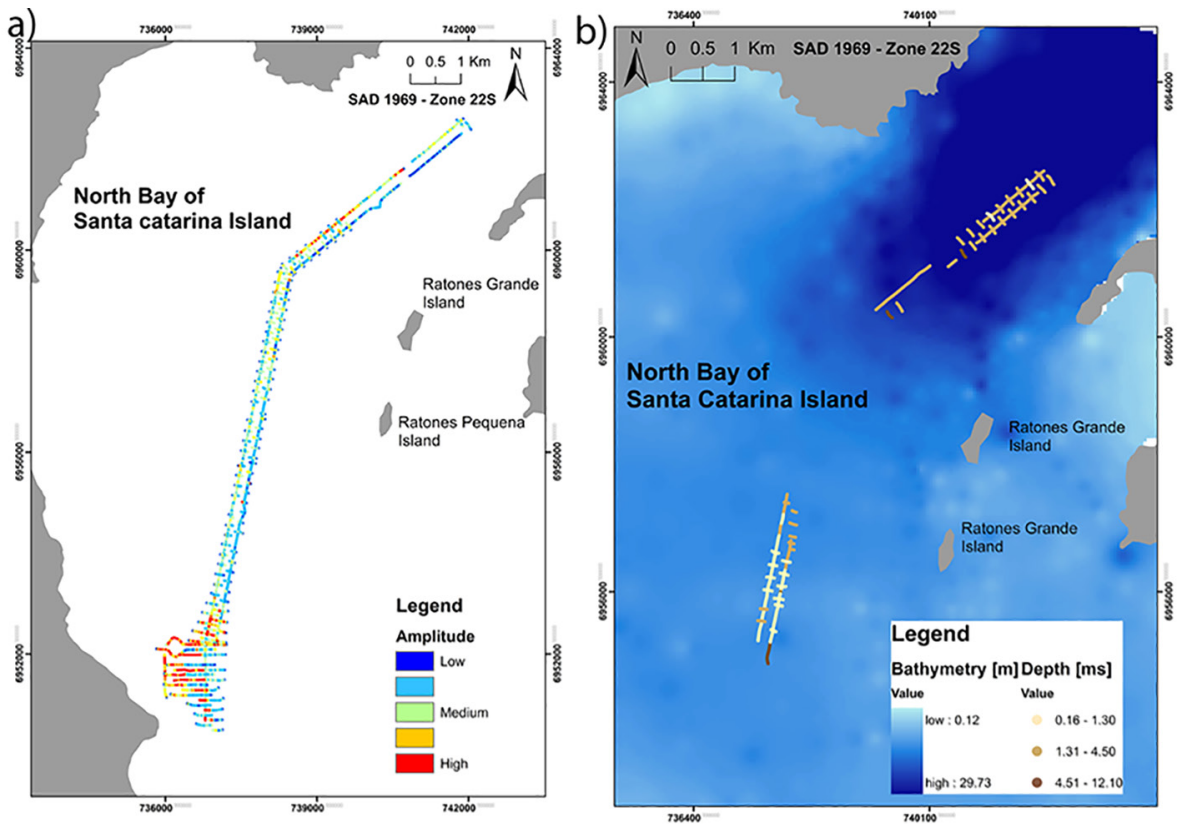

Figure 7. The amplitude (reflectivity) of the North Bay floor (a) and the distribution of depths of gas (b).

Blanking and Black Shadow) and Pockmarks, which are arranged randomly, even though in some places their configuration tend to be linear. They have been interpreted as the morphological expression of gas leakage, representing different erosion stages and can be very important to biological productivity (DRISCOLL; UCHUPI, 1997; DANDO et al., 1994). The maps indicate different features and how close gas accumulation is to the sediment surface - except in a few sections in the north and south-central portions of the lagoon (between 7.91 and $8.20 \mathrm{~ms}$ ), where they are associated with paleotopographic depressions such as fluvial channels and/ or valleys. The depths of these shallow gas structures are evidenced by BATAGLION et al. (2012) who analyzed cores in the Conceição Lagoon, in which it was verified that the 

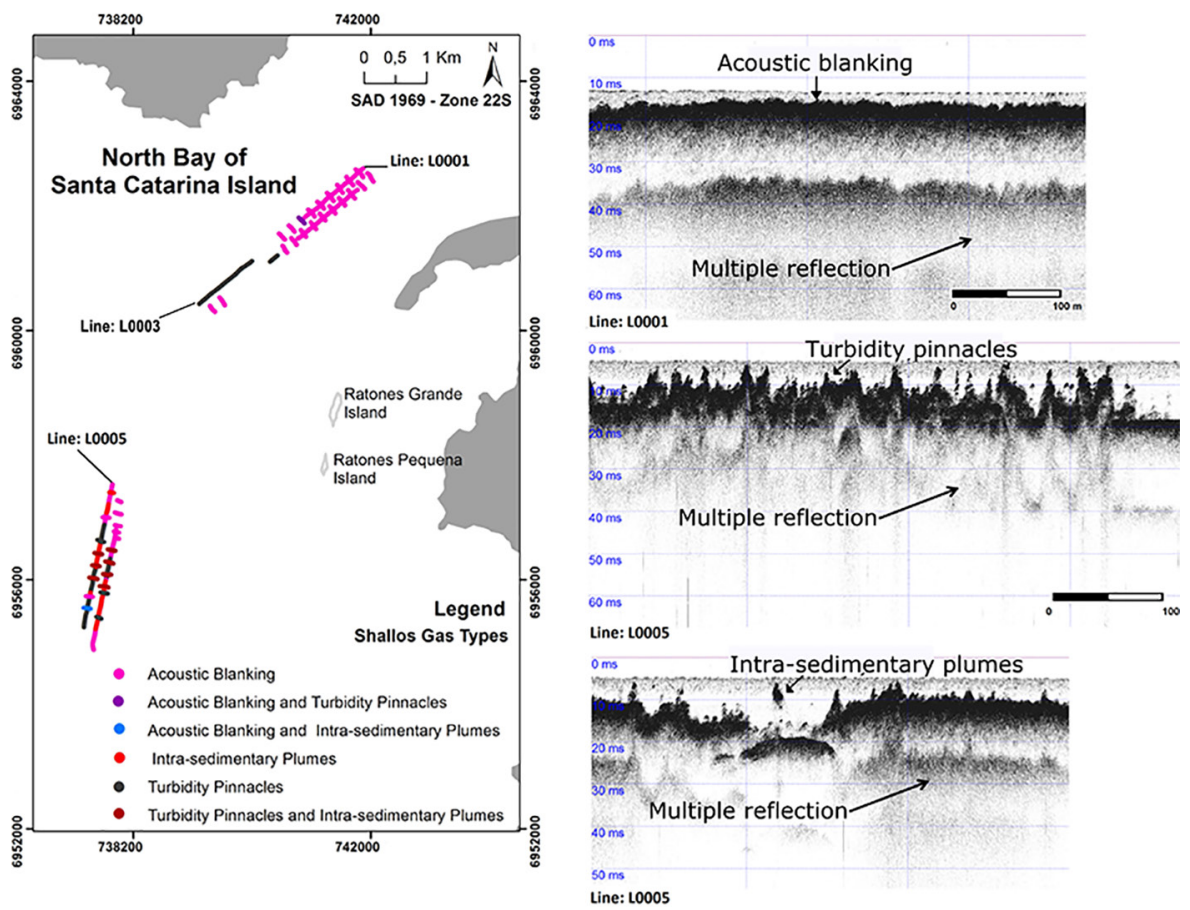

Figure 8. The different structures of gas features contained within the North Bay: Acoustic Blanking, Turbidity Pinnacles and Intra-sedimentary plume.

highest sedimentation occurred between1994 and 2011, a period in which a greater amount of organic material was also observed in the environment at approximately $0.50 \mathrm{~m}$ depth. Furthermore, it was confirmed that it is a reducing environment, mainly at the sediment- water interface. On the other hand, in some cases, as in the presence of some gas profiles (Black Shadows), they can be mistaken for sandy locations as sand is highly reflective, and the site is shallow. This pattern may be confirmed by the bathymetry map of the Conceição Lagoon and the amplitude (Figure 6a).

In the North Bay, the most common feature of shallow gas is Acoustic Blanking. According to IGLESIAS and GARCÍA-GIL (2007), this is a variation of the front cover which appears as an Acoustic Blanking tent, completely obscuring the underlying reflectors which rise to $1 \mathrm{~m}$ above the mean gas front, sometimes reaching the seabed.

The longer seismic profiles, presented in Figure 9, show a relation between a paleochannel and the shallow gas features of the North Bay. The gas accumulations lie inside the low paleotopographic structure, which blocks the signal, prevents the visualization of the bottom and the tracing of this paleochannel. It may indicate the accumulation of organic matter in these paleoenvironments which were then drowned and filled in by subsequent transgressive events.

BONETTI (2007) investigated, through organic geochemical analysis, samples of surface sediment and one of the observed parameters in North Bay was total sulfur.
The presence of gas pockets in the central portion of the North Bay of the Santa Catarina Island seems to coincide with the concentration of total sulfur in the surface sediments (Figure 10), which is comparatively higher than in its surroundings (SOUZA et al., 2011). A richer sulfur content in the surface sediments close to those features corroborates the hypothesis that those gases may be escaping from the sedimentary column (SOUZA et al., 2011, BONETTI et al., 2007). Although there exists the co-occurrence of gas features and sediment enriched by total sulfur in the study area, the correlation between them is very complex, as discussed by HILL et al. (1992).

\section{CONCLUSION}

A better understanding of the associated seismic features, and their classification, has strong implications both in environmental analysis and engineering activities. In the study area of the Conceição Lagoon and the North Bay, six types of gas structures (leaks and features) have been described according to their specific seismic signature or echo-characters: Acoustic Plumes, Intra-sedimentary plumes, Pockmarks, Acoustic blanking, Black shadow and Turbidity Pinnacles.

In the Conceição Lagoon the most common feature found in the seismic records is Acoustic Blanking, followed by Acoustic Plumes and Black Shadows. These 


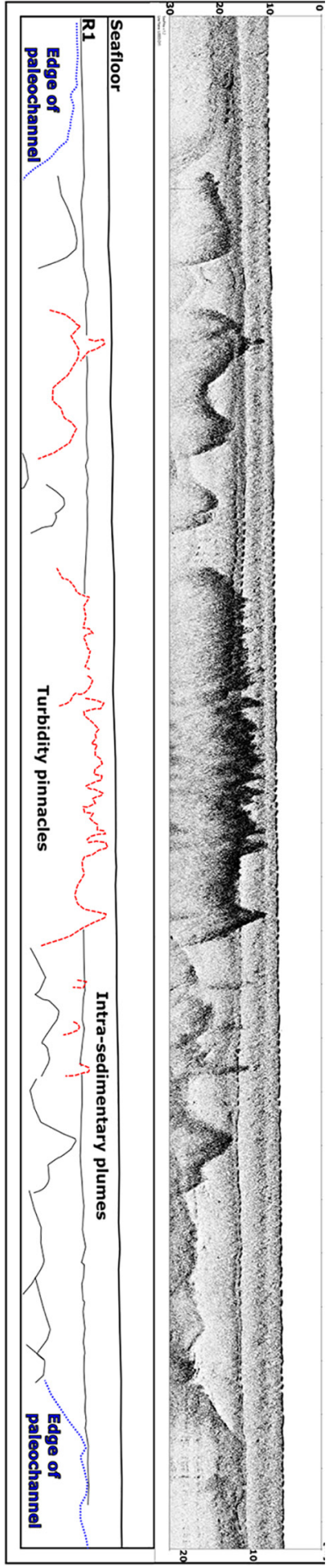

Figure 9. The relation between palochannel and shallow gas accumulation from a North Bay seismic profile, line L0003.

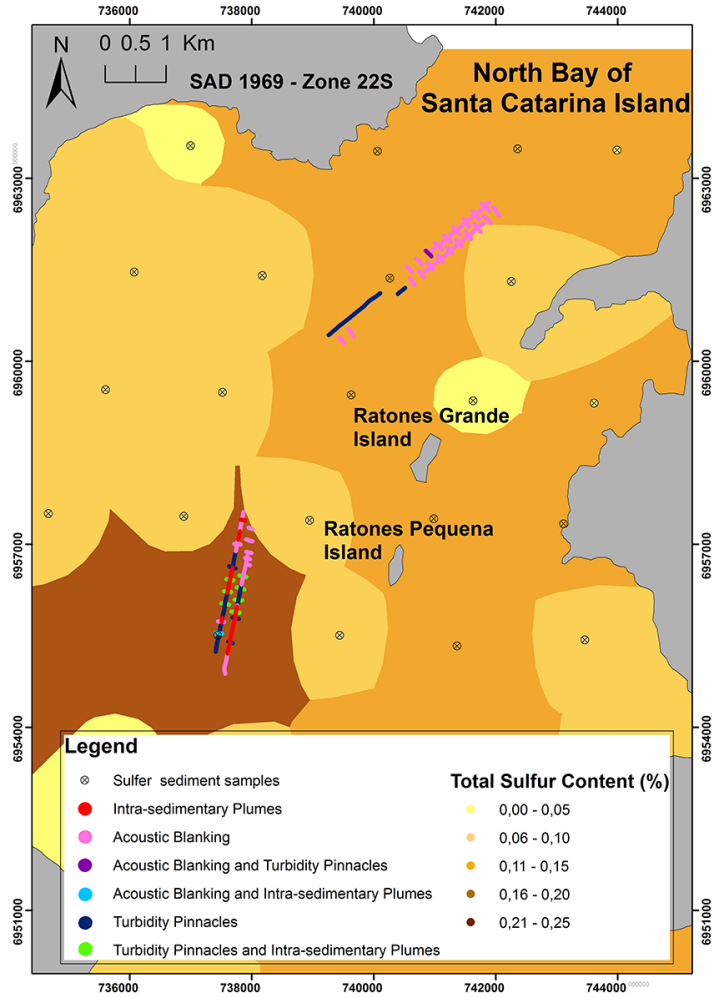

Figure 10. Comparison between profiles containing gases and total sulfur (SO4) in the surface sediments (Modified from Bonetti et al., 2007 and Souza et al., 2011).

accumulations are usually found close to the surface of the sediment column. Only in the southern part of the lagoon system were they found to be deeper in the sediments, at approximately $10 \mathrm{~ms}$. On the floor of the lagoon system pockmarks are present and their diameters vary in size from $0.64 \mathrm{~m}$ to $1.39 \mathrm{~m}$ and present a density from 53 to 239 units per $50 \mathrm{~m}^{2}$.

Three types of shallow gas features appear in the North Bay seismic profile, Acoustic Blanking, Turbidity Pinnacles and Intra-sedimentary Plumes. Sometimes they are found associated with other features, but normally they appear isolated. The most common shallow gas feature in the North Bay is Acoustic Blanking - normally in the northern part of the bay. It is characterized by a transparent or signal-starved domain in the seismic section, as the result of the attenuation of the acoustic signal caused by the gas in the sediments. Those gas accumulation features match spots of a higher concentration of total sulfur. However, the presence of a possible causal relationship between these variables should be investigated in future studies. 
The gas accumulation identified in the Conceição Lagoon is closer to the seafloor surface than it is in the North Bay. The reason for this is that the formation of the gas is more recent, so the organic matter deposited in the Lagoon is also more recent than that in the Bay. That is also the reason for the detection of the escaping fluid into the water column as Acoustic Plume and Pockmark.

The features described in the high-resolution seismic records, by the side scan sonar, photography and the content of total sulfur demonstrate that gas escapes into the water column in both environments and that the pockets of gas are related to the depressions or paleoriver valleys - as has been described in the literature in relation to various places around the world.

\section{ACKNOWLEDGEMENTS}

The authors wish to thank Prof. Dr. Carla Bonetti (Project CNPq no: 401851/2010-9) for the Conceição Lagoon data and PROSUL/CB\&I for the seismic data of the North Bay. We would also thank CNPQ/PIBIC-UFSC and CNPQ for the research fellowship.

\section{REFERENCES}

ANGULO, R. J.; LESSA, G. C. The Brazilian sea-level curves: a critical review with emphasis on the curves from Paranaguá and Cananéia regions. Mar. Geol., v. 140, p. 141-166, 1997.

ANGUlO, R. J.; LESSA, G. C.; SOUZA, M. C. A critical review of mid- to late-Holocene sea-level fluctuations on the eastern Brazilian coastline. Quat. Sci. Rev., v. 25, n. 5-6, p. 486-506, 2006

ANGULO, R. J.; LESSA, G. C.; SOUZA, M. C. The Holocene barrier systems of Paranaguá and northern Santa Catarina coasts, southern Brazil. In: DILLENBURG, S.; HESP, P. (Eds.). Geology and Geomorphology of Holocene Coastal Barriers of Brazil. Berlin: Springer, 2009. p. 2-44.

BALTZER, A.; TESSIER B.; NOUZÉ, H.; BATES, R.; MOORE, C.; MENIER, D. Seistec Seismic Profiles: a Tool to Differentiate Gas Signatures. Mar. Geophys. Res., v. 26, n. 2-4, p. 235-245, 2005

BAPTISTA NETO, J. A.; SILVA, M. A. M.; FIGUEIREDO JR, A. G. Sísmica de alta freqüência e o padrão de distribuição de sedimentos na Enseada de Jurujuba (Baía de Guanabara) - RJ/ Brasil. Rev. Bras. Geof., v. 14, n. 1, p. 51-57, 1996.

BAPTISTA NETO, J. A.; SILVA, C. G.; DIAS, G. T. M.; FONSECA, E. M. Distribuição sedimentar na Lagoa Rodrigo de Freitas através de sísmica de alta resolução. Rev. Bras. Geof., v. 29, n. 1, p. 187-195, 2011.

BATAGLiOn, G. A.; PUHL, P. R.; RAU, M.; DAMATTO, S. R.; MADUREIRA, L. A. S. Avaliação de Compostos Lipídicos em Ambiente Anóxico da Lagoa da Conceição, Ilha de Santa Catarina, Brasil. Rev. Virtual Quím., v. 4, n. 4, p. 474-489, 2012.
BENITES, M.; ALVES, D. P.; MALY, M. S.; JOVANE, L. Shallow gas occurrence in a Brazilian ría (Saco do Mamanguá, Rio de Janeiro) inferred from high-resolution seismic data. Cont. Shelf. Res., v. 108, p. 89-96, 2015.

BEST, A. I.; TUFFIN, M. D. J.; DIX, J. K.; BULL, J. M. Tidal height and frequency dependence of acoustic velocity and attenuation in shallow gassy marine sediments. J. Geophys. Res. Solid Earth, v. 109, n. B8, p.101, 2004.

BONETTI, C.; BONETTI, J.; BARCELOS, R. L. Caracterização sedimentar e geoquímica de sistemas costeiros com ênfase na avaliação da influência de sítios de cultivo de moluscos. In: BARROSO, G. F.; POERSCH, L. H. S.; CAVALLI, R. O.; GALVEZ, A. O. (Orgs.). Sistemas de cultivos aqüícolas costeiros no Brasil: recursos, tecnologias e aspectos ambientais e sócio-econômicos. Rio de Janeiro: Museu Nacional, 2007. p. 139-149.

CARUSO JR, F.; SUGUIO, K.; NAKAMURA, T. The Quaternary geological history of the Santa Catarina southeastern region (Brazil). An. Acad. Bras. Ciênc., v. 72, n. 2, p. 257-270, 2000.

CARUSO JR, F.; AWDZIEJ, J. Mapa geológico da ilha de Santa Catarina. Scale 1:100,000, 1 sheet. Brasília: UFRGS, DNPM, PETROBRÁS, 1993.

CATANZARO, L. F.; BAPTISTA NETO, J. A.; GUIMARÃES, M. S. D.; SILVA, C. G. Distinctive sedimentary processes in Guanabara Bay - SE/Brazil, based on the analysis of echocharacter (7.0 kHz). Rev. Bras. Geof., v. 22, n. 1, p. 69-83, 2004.

COSTA, E. A.; FIGUEIREDO JR, A. G. Echo-Character and Sedimentary Processes on the Amazon Continental Shelf. An. Acad. Bras. Ciênc., v. 70, n. 2, p. 187-200, 1998.

DAMUTH, J. E. Echo Character of the western equatorial Alantic floor and its relationship to the dispersal and districution of terrigenous sediments. Mar. Geol., v. 18, p. 17-45, 1975.

DANDO, P. R.; JENSEN, P.; O'HARA, S. C. M.; NIVEN, S. J.; SCHMALJOHANN, R.; SCHUSTER, U.; TAYLOR, L. $\mathrm{J}$. The effects of methane seepage at an intertidal/shallow subtidal site on the shore of the Kattegat, Vendsyssel, Denmark. Bull. Geol. Soc. Den., v. 41, p. 65-79, 1994.

DEMARCO, L. F. W.; GUESSER, V.; KLEIN, A. H. F.; AYRES, A.; FELIX, C.; BONETTI, J. Identificação de feições acústicas rasas de gás na Lagoa da Conceição, Ilha de Santa Catarina, SC. In: Congresso Brasileiro de Oceanografia. Rio de Janeiro: Congresso Brasileiro de Oceanografia, 2012.

DIEZ，R.; GARCÍA-GIL，S.; DURÁN，R.; VILAS，F. Gas accumulations and their association with particle size distribution patterns in the Ría de Arousa seabed (Galicia, NW Spain): an application of discriminant analysis. Geo-Mar. Lett., v. 27, n. 2-4, p. 89-102, 2007.

DOMINGUEZ, J. M. L. The coastal zone of Brazil. In: DILLENBURG, S.; HESP, P. (Eds.). Geology and Geomorphology of Holocene Coastal Barriers of Brazil. Berlin: Springer, 2009. p. 17-51.

DRISCOLL, N.; UCHUPI, E. The importance of gas and grondwater seepage in landscape and seascape evolution. Thalassas: Int. J. Mar. Sci., v.13, n. 1, p. 35-48, 1997.

DUARTE, H.; PINHEIRO, L. M.; TEIXEIRA, F. C.; MONTEIRO, J. H. High-resolution seismic imaging of gas accumulations and seepage in the sediments of the Ria de Aveiro barrier lagoon (Portugal). Geo-Mar. Lett., v. 27, n. 2, p. $115-126,2007$. 
EMEIS, K. C.; BRÜCHERT, V.; CURRIE, B.; ENDLER, R.; FERDELMAN, T.; KIESSLING, A.; LEIPE, T.; NOLIPEARD, K.; STRUCK, U.; VOGT, T. Shallow gas in shelf sediments of the Namibian coastal upwelling ecosystem. Cont. Shelf Res., v. 24, n. 6, p. 627-642, 2004.

FÉLIX, C. A. Evolução Quaternária Superior e Formação de Gás Raso em Ambiente Estuarino Tropical: O Caso do Canal de Bertioga. 2012. 96f. Dissertação (Mestrado) - Universidade de São Paulo, Instituto Oceanográfico. São Paulo, 2012. http:// www.teses.usp.br/teses/disponiveis/21/21136/tde-11122012133235/pt-br.php

FRAZÃO, E.; VITAL, H. Estruturas rasas de gás em sedimentos no estuário Potengi (Nordeste do Brasil). Rev. Bras. Geof., v. 25, n. 1, p. 17-26, 2007.

FIGUEIREDO JR, A. G.; NITTROUER, C. A. New insights to high-resolution stratigraphy on the Amazon continental shelf. Mar. Geol., v. 125, n. 3-4, p. 393-399, 1995.

FIGUEIREDO JR, A. G.; NITTROUER, C. A.; COSTA, E. A. Gas-charged sediments in the Amazon submarine delta. GeoMar. Lett., v. 16, n. 1, p. 31-35, 1996.

GARCIA-GIL, S.; VILAS, F.; GARCÍA-GARCÍA, A. Shallow gas features in incised-valley fills (Ría de Vigo, NW Spain): a case study. Cont. Shelf Res., v. 22, n. 16, p. 2303-2315, 2002.

GARCÍA-GARCÍA, A.; ORANGE, D. L.; MISEROCCHI, S.; CORREGGIARI, A.; LANGONE, L.; LORENSON, T. D.; TRINCARDI, F.; NITTROUER, C. A. What controls the distribution of shallow gas in the Western Adriatic Sea? Cont. Shelf Res., v. 27, n. 3-4, p. 359-374, 2007.

GASPERINI, L.; STANGHELLINI, G. SEISPRHO: An interactive computer program for processing and interpretation of high-resolution seismic reflection profiles. Comput. Geosci., v. 35, n. 7, p. 1497-1507, 2009.

GORGAS, T. J.; KIM, G. Y.; PARK, S. C.; WILKENS, R. H.; KIM, D. C.; LEE, G. H.; SEO, Y. K. Evidence for gassy sediments on the inner shelf of SE Korea from geoacoustic properties. Cont. Shelf Res., v. 23, n. 8, p. 821-834, 2003.

GRÉ, J. C. R.; HORN FILHO, N. O. Caracterização Textural dos Sedimentos de Fundo da Lagoa da Conceição, Ilha de Santa Catarina, SC, Brasil. In: SIERRA de LEDO, B.; SOFIANOSERRA, E. J. (Eds.). O Ecossistema da Lagoa da Conceição. Floriánópolis: NEMAR/CCB/UFSC, SDMEEPEMA, 1999. p. 25-34.

GUESSER, V.; DEMARCO, L. F. W.; KLEIN, A. H. F.; AYRES NETO, A.; FELIX, C.; SOUZA, J.; BONETTI, J. Identificação das feições rasas de gás na região da Lagoa da Conceição e da Baía Norte na Ilha de Santa Catarina. In: V Simpósio Brasileiro de Geofísica. Salvador: V Simpósio Brasileiro de Geofísica, 2012.

HEIN, C. J.; FITZGERALD, D. M.; CLEARY, W. J.; ALBERNAZ, M. B.; MENEZES, J. T.; KLEIN, A. H. F. Evidence for a transgressive barrier within a regressive strandplain system: Implications for complex coastal response to environmental change. Sedimentology, v. 60, n. 2, p. 469-502, 2013.

HEIN, C. J.; FITZGERALD, D. M.; MENEZES, J. T.; CLEARY, W. J.; KLEIN, A. H. F.; ALBERNAZ, M. B. Coastal response to late-stage transgression and sea-level highstand. Geol. Soc. Am. Bull., v. 126, n. 3-4, p. 459-480, 2014.

HESP, P. A.; GIANNINI, P. C. F.; MARTINHO, C. T.; MOIT DA SILVA, G.; ASP NETO, N. E. The Holocene barrier systems of the Santa Catarina coast, southern Brazil. In: DILLENBURG, S. R.; HESP, P. A. (Eds.). Geology and Geomorphology of Holocene Coastal Barriers of Brazil. Berlin: Springer, 2009. p. 94-133.
HILL, J. M.; HALKA, J. P.; CONKWRIGHT, R.; KOCZOT, K.; COLEMAN, S. Coleman Coleman Coleman ${ }^{\dagger}$ Distribution and effects of shallow gas on bulk estuarine sediment properties. Cont. Shelf Res., v. 12, n. 10, p. 1219-1229, 1992.

HORN FILHO, N. O.; ABREU DE CASTILHOS, J.; GRÉ, J. C. R. The coastal Pleistocene of the State of Santa Catarina, southern Brazil. In: RABASSA, J.; SALEMME, M. (Eds.). Quaternary of South America and Antarctic Peninsula. Rotterdam: Balkema, 1997. p. 45-54.

HOVLAND, M.; JUDD, A. G. Seabed Pockmarks and Seepages. Impact on Geology, Biology and the Marine Environment. London: Graham and Trotman, 1988. 294 p.

IGLESIAS, J.; GARCÍA-GIL, S. High-resolution mapping of shallow gas accumulations and gas seeps in San Simón Bay (Ría de Vigo, NW Spain). Some quantitative data. Geo-Mar. Lett., v. 27, n. 2, p. 103-114, 2007.

JENSEN, J. B.; BENNIKE, O. Geological setting as background for methane distribution in Holocene mud deposits, Århus Bay, Denmark. Cont. Shelf Res., v. 29, n. 5-6, p. 775-784, 2009.

JUDD, A.; DAVIES, G.; WILSON, J.; HOLMES, R.; BARON, G.; BRYDEN, I. Contributions to atmospheric methane by natural gas seepage on the UK continental shelf. Mar. Geol., v. 137, n. 1-2, p. 165-189, 1997.

KARNAUKH, V. N.; ASTAKHOV, A. S.; VERESHCHAGINA, O. F.; TSOY, I. B.; KOSMACH, D. A.; SAGALAEV, S. G.; VOLKOVA, T. I.; DUBINA, V. A.; PRUSHKOVSKAYA, I. A. Formation of subsurface shallow gas accumulations in Amurskiy Bay (Peter the Great Bay, Sea of Japan) as a result of postglacial sea-level change, paleoceanographic conditions and hydrological activity. Mar. Geol., v. 372, p. 31-52, 2016.

KING, L. H.; MACLEAN, B. Pockmark on the Scotian Shelf. Geol. Soc. Am. Bull., v. 81, n. 10, p. 3141-3148, 1970.

KLEIN, A. H. F.; FERREIRA, O.; DIAS, J. M. A.; TESSLER, M. G.; SILVEIRA, L. F.; BENEDET, L.; MENEZES, J. T.; ABREU, J. G. N. Morphodynamics of structurally controlled headland-bay beaches in southeastern Brazil: A review. Coast. Eng., v. 57, n. 2, p. 98-111, 2010.

LAFFERTY, B.; QUINN, R.; BREEN, C. A side-scan sonar and high-resolution Chirp sub-bottom profile study of the natural and anthropogenic sedimentary record of Lower Lough Erne, northwestern Ireland. J. Archaeol. Sci., v. 33, n. 6, p. 756-766, 2006.

LEE, S. H.; CHOUGH, S. K.; BACK, G. G.; KIM, Y. B. Chirp $\left(2^{\wedge} 7-\mathrm{kHz}\right)$ echo characters of the South Korea Plateau, East Sea: styles of mass movement and sediment gravity low. Mar. Geol., v. 184, n. 3-4, p. 227-247, 2002.

LEE, G. H.; KIM, D. C.; KIM, H. J.; JOU, H. T.; LEE, Y. J. Shallow gas in the central part of the Korea Strait shelf mud off the southeastern coast of Korea. Cont. Shelf Res., v. 25, n. 16, p. 2036-2052, 2005.

MARTIN, L.; SUGUIO, K.; FLEXOR, J. M.; AZEVEDO, A. E. G. Mapa geológico do Quaternário costeiro dos estados do Paraná e Santa Catarina. Brasília: DNPM, 1988. 40 p.

MAZUMDAR, A.; PEKETI, A.; DEWANGAN, P.; BADESAB, F.; RAMPRASAD, T.; RAMANA, M. V.; PATIL, D. J.; DAYA, A. Shallow gas charged sediments off the Indian west coast: Genesis and distribution. Mar. Geol., v. 267, n. 1-2, p. 71-85, 2009.

MCBRIDE, R. A.; ANDERSON, J.; BUYNEVICH, I. V.; CLEARY, W. J.; FENSTER, M. S.; FITZGERALD, D. M.; HARRIS, M. S.; HEIN, C. J.; LIU, B.; MENEZES, J. T.; PEJRUP, M.; RIGGS, S. R.; SHORT, A. D.; STONE, G. W.; 
WALLACE, D. J.; WANG, P. Morphodynamics of Barrier Systems: a Synthesis. In: SHRODER, J.; SHERMAN, D. J. (Eds.). Treatise on Geomorphology (Coastal and Submarine Geomorphology). 1st ed. San Diego: Academic Press, 2013. p. $174-244$.

MISSIAEN, T.; MURPHY, S.; LONCKE, L.; HENRIET, J. P. Very high-resolution seismic mapping of shallow gas in the Belgian coastal zone. Cont. Shelf Res., v. 22, n. 16, p. 22912301, 2002.

MitroviCA, J. X.; MILNE, G. A. On the origin of late Holocene sea-level highstands within equatorial ocean basins. Quat. Sci. Rev., v. 21, n. 20-22, p. 2179- 2190, 2002.

ORANGE, D.; GARCÍA-GARCÍA, A.; LORENSON, T.; NITTROUER, C.; MILLIGAN, T.; MISEROCCHI, S., LANGONE, L.; CORREGGIARI, A.; TRINCARDI, F. Shallow gas and flood deposition on the Po Delta. Mar. Geol., v. 222-223, p. 159-177, 2005.

PREMCHITT, J.; RAD, N. S.; TO, P.; SHAW, R.; JAMES, J. W. C. A study of gas in marine sediments in Hong Kong. Cont. Shelf Res., v. 12, n. 10, p. 1251-1264, 1992.

QUARESMA, V. S.; DIAS, G. T. M.; BAPTISTA NETO, J. A. Caracterização da ocorrência de padrões de sonar de varredura lateral e sísmica de alta freqüência $(3,5$ e 7,0 kHz) na porção sul da Baía de Guanabara - RJ. Rev. Bras. Geof., v. 18 , n. 2, p. 201-214, 2000.

SCHAROOT, B. M.; SCHÜTTENHELM, R. T. E. Expressions of the shallow gas in the Nertherlands North Sea. Neth. J. Geosci., v. 82, n. 1, p. 91-105, 2003.

SCHWARZER, K.; STATTEGGER, K.; VITAL, H.; BECKER, M. Holocene coastal evolution of the Rio Açu Area (Rio Grande do Norte, Brazil). J. Coast. Res., n. 39, v. 1, p. 141$145,2006$.

SOUZA, J.; TESSLER, T.; FELIX, C.; FRANKLIN, L.; BENEDET, L.; SUTHARD, B.; DEMARCO, L. F. W.; BONETTI, J.; KLEIN, A. H. F. Gas features detected with ultra shallow water high resolution seismic in the North Bay, Santa Catarina state, Southern Brazil. In: XIV Congresso Latino Americano de Ciências do Mar. Balneário Camboriú: AOCEANO; 2011.

SUGUIO, K.; MARTIN, L.; BITTENCOURT, A. C. S. P.; DOMINGUEZ, J. M. L.; FLEXOR, J. M.; AZEVEDO, A. E. G. Flutuações do nível relativo do mar durante o Quaternário Superior ao longo do litoral brasileiro e suas implicações na sedimentação costeira. Rev. Bras. Geoc., v. 15, n. 4, p. 273$286,1985$.

TAYLOR, D. I. Nearshore shallow gas around the U.K. coast. Cont. Shelf Res., v. 12, n. 10, p. 1135-1144, 1992.

VITAL, H.; STATTEGGER, H. Gas-Charged Sediments on the Lowermost Amazon River. Anais do $5^{\circ}$ Cong. Int. Soc. Bras. Geof., São Paulo, v. 1, p. 85-88, 1997.

VILLWOCK, J A.; TOMAZELLI, L. J.; LOSS, E. L.; DEHNHARDT, E. A.; HORN, N. O.; BACHI, F. A.; DEHNHARDT, B. A. Geology of the Rio Grande do Sul coastal province. In: RABASSA, J. (Ed.). Quaternary of South America and the Antarctic Peninsula. Balkema: Rotterdam, 1986. p. 79-97.

WESCHENFELDER, J.; CORREAA, I. C. S.; ALIOTTA, S.; PEREIRA, C. M.; VASCONCELLOS, V. E. B. Shallow gas accumulation in sediments of the Patos Lagoon, southern Brazil. An. Acad. Bras. Ciênc., v. 78, n. 3, p. 607-614, 2006.

WESCHENFELDER, J.; KLEIN, A. H. F.; GREEN, A. N.; ALIOTTA, S.; MAHIQUES, M. M.; AYRES NETO, A.; TERRA, L. C.; CORRÊA, I. C. S.; CALLIARI, L. J.; MONTOYA, I.; GINSBERG, S. S.; GRIEP, G. H. The control of palaeo-topography in the preservation of shallow gas accumulation: Examples from Brazil, Argentina and South Africa. Estuar. Coas. Shel Sci., v. 172, p. 93-107, 2016.

ZALAN, P. V.; OLIVEIRA, J. A. B. Origem e evolução estrutural do Sistema de Riftes Cenozóicos do Sudeste do Brasil. Bol. Geosc. Petrobras, v. 13, n. 2, p. 269-300, 2005. 
